\title{
PLURALISME PENGATURAN UMUR KECAKAPAN DALAM PEMBEBANAN HAK TANGGUNGAN
}

\section{Made Widana Putra*, Dr. Putu Tuni Cakabawa Landra, SH., M.Hum.**, I Made Pria Darsana, SH., M.Hum.***}

Magister Kenotariatan Universitas Udayana

E-mail : justwide@rocketmail.com

\section{ABSTRACT \\ PLURALISM IN AGE REQUIEREMENTS TO CONCLUDE A MORTGAGE GRANTING}

SKMHT (Power of Attorney to Grant a Mortgage) shall be concluded through a notarial deed or Land Conveyancer's deed as regulated in Article 15 paragraph (1) of Law No. 4 of 1996. Article 39 paragraph (1) of Law No. 30 of 2004 in conjunction with Law No. 2 of 2014 stipulate that an appearer before a Notary Public shall be minimum eighteen (18) years old. However, to conclude an SKMHT, PPAT (Land Conveyancer) applies the age requirement of minimum twenty-one (21) years old as regulated in the provision of article 330 of $B W$ (Civil Code of the Republic of Indonesia). As such, there are two (2) contradictive age requirements to conclude an SKMHT, namely horizontal norm conflict (geschijld van normen) between Article 330 of $B W$ and Article 39 paragraph (1) of Law No. 30 of 2004 in conjunction with Law No. 2 of 2004. Apart from the two (2) provisions referred to above, Law No. 1 of 1974 also regulates the age requirement, namely article 47 and article 50. The validity of SKMHT will affect the execution of APHT (Deed of Mortgage Granting) and the registration of mortgage granting. Based on the said backgrounds, the main subject of this study is what the age requirement should be in order to able to conclude an SKMHT, APHT and to register a Mortgage Granting.

This study constitutes a normative legal study derived from the existing norm conflict between article 330 of $B W$ and article 39 paragraph (1) of Law No. 30 of 2004 in conjunction with Law No. 2 of 2014, and among article 330 of $B W$ and article 47, article 50 and article 66 of Law No. 1 of 1974. Meanwhile, this study adopts the Statue Approach and Analytical \& Conceptual Approach. The legal stuff resources come from primary legal stuff resources and secondary legal stuff resources. The methodology to collect legal stuff resources is the snow ball principle, where the resources were inventoried and identified in order to able to analyze the existing problems in this study.

The results of this legal study indicate that normatively, an SKMHT shall be concluded by using the age requirement of eighteen (18) years old. However, Notary Public and PPAT in practice remain to adopt the age requirement of twenty-one (21) years old to conclude an SKMHT. PPAT should also apply the age requirement of eighteen (18) years old to conclude APHT. However, PPAT in practice remain to adopt the age requirement of twenty-one (21) years old. Therefore, the process to conclude an APHT will not be able to be carried out if the subject of notarized SKMHT is eighteen (18) years old. The same also applies to the registration of mortgage granting at the Land Office because the Land Office requires the age requirement of twenty-one (21) years old as regulated in the provision of Article 330 of $B W$. As a consequence, if the subject has not yet reached the minimum age requirement, the mortgage granting cannot be registered.

Keywords: Notary Public, PPAT (Land Conveyancer), SKMHT (Power of Attorney to Grant a Mortgage), APHT (Deed of Mortgage Granting) and Registration of Mortgage Granting

\section{PENDAHULUAN}

\subsection{Latar Belakang Masalah}

Kecakapan orang perseorangan berdasarkan batasan umur untuk membuat SKMHT dalam bentuk akta notaris maupun akta PPAT masih terjadi ketidakpastian hukum. UU No. 4 Tahun 1996 sebagai dasar hukum 
hak tanggungan tidak menentukan batas umur cakap membuat SKMHT. Pasal 39 ayat (1) UU No. 30 Tahun 2004 jo. UU No.2 Tahun 2014 mengatur bahwa penghadap harus memenuhi syarat paling sedikit berumur 18 (delapan belas) tahun atau telah menikah dan cakap melakukan perbuatan hukum. PPAT mendasarkan kecakapan orang perseorangan berdasarkan pasal $330 \mathrm{BW}$, yaitu 21 (duapuluh satu) tahun atau telah kawin. Dengan demikian ada 2 (dua) ketentuan mengenai batasan umur bagi orang perseorangan untuk dapat membuat SKMHT, yaitu 18 (delapanbelas) tahun dan 21 (duapuluh satu) tahun. Hal itu telah menimbulkan konflik norma (geschijld van normen) secara horizontal antara pasal 330 BW dengan pasal 39 ayat (1) UU No. 30 Tahun 2004 jo. UU No.2 Tahun 2014. Apabila SKMHT tersebut berakibat batal karena ketidak cakapan subjeknya, maka akan sangat berpengaruh pada proses pembebanan hak tanggungan.

\subsection{Rumusan Masalah}

Berdasarkan uraian latar belakang diatas, maka ada 2 (dua) permasalahan yang akan dibahas dalam penelitian ini, yaitu ;

1. Berapakah batasan umur kecakapan membuat SKMHT ?

2. Berapakah batasan umur kecakapan membuat Akta Pemberian Hak Tanggungan (APHT) dan pendaftaran hak tanggungan?

\subsection{Tujuan Penelitian}

Tujuan penelitian ini dilakukan dengan maksud untuk mencapai tujuan yang bersifat umum dan khusus.

\subsection{Manfaat Penelitian}

Hasil penelitian ini diharapkan dapat bermanfaaat bagi perkembangan bidang ilmu hukum (manfaat teoritis) dan manfaat bagi kepentingan praktis.

\subsection{Landasan Teoritis}

Adapun teori dan asas hukum yang digunakan mengkaji permasalahan dalam penelitian ini adalah sebagai berikut :

\subsubsection{Teori Kedaulatan Hukum}

Menurut teori kedaulatan hukum, yang berdaulat adalah hukum. Maksudnya, pemerintah maupun rakyat mendapat kekuasaan dari hukum. ${ }^{1}$ Inilah yang dinamakan prinsip negara hukum, yang mengutamakan kedaulatan hukum, prinsip supremasi hukum (supremacy of law), atau kekuasaan tertinggi di tangan hukum. ${ }^{2}$

\subsubsection{Teori Sistem Hukum}

Dalam setiap sistem hukum terdapat tiga unsur, sebagai berikut ;

a. Struktur, yaitu keseluruhan institusi-institusi hukum yang ada beserta aparatnya, mencakupi antara lain kepolisian dengan para polisinya, kejaksaan dengan para jaksanya, pengadilan dengan para hakimnya, dan lain-lain;

b. Substansi, yaitu keseluruhan aturan hukum, norma hukum dan asas hukum, baik yang tertulis maupun yang tidak tertulis, termasuk putusan pengadilan;

${ }^{1}$ Sudarsono, 2007, Pengantar Ilmu Hukum, cet.V, Rineka Cipta, Jakarta, h.111.

2 Jimly Asshiddiqie, 2005, Konstitusi dan Konstitusionalisme Indonesia, Konpress, Jakarta, h.151. 
c. Kultur hukum, yaitu opini-opini, kepercayaan-kepercayaan (keyakinankeyakinan), kebiasaan-kebiasaan, cara berpikir, dan cara bertindak, baik dari para penegak hukum maupun dari warga masyarakat, tentang hukum dan berbagai fenomena yang berkaitan dengan hukum. ${ }^{3}$

\subsubsection{Teori Kewenangan}

Kewenangan yang bersumber dari peraturan perundang-undangan tersebut diperoleh melalui tiga cara, yaitu atribusi, delegasi, dan mandat. ${ }^{4}$ Philipus M. Hadjon mengemukakan mengenai kewenangan pada hakikatnya berasal dari 2 (dua) sumber yaitu atribusi dan delegasi. Namun dikatakan pula bahwa kadangkala mandat digunakan sebagai cara tersendiri dalam memperoleh wewenang. 5

\subsubsection{Teori Keberlakuan Hukum}

Menurut Bruggink ada 3 (tiga) macam keberlakukan hukum yaitu: ${ }^{6}$

1. Keberlakuan Faktual atau Empiris Kaidah Hukum.

2. Keberlakuan Formal atau Formal Kaidah Hukum.

3. Keberlakuan Evaluatif Kaidah Hukum.

\subsubsection{Asas Kepastian Hukum}

Terkait dengan kepastian hukum, Lon L. Fuller memajukan delapan asas yang harus dipenuhi oleh hukum apabila itu tidak dipenuhi, maka gagallah hukum disebut sebagai

3 Achmad Ali, 2009, Menguak Teori Hukum (Legal Theory) dan Teori Peradilan (Judicialprudence), Kencana, Jakarta, hal.204.

${ }^{4}$ Ridwan HR., 2006, Hukum Administrasi Negara, Raja Grafmdo Persada, Jakarta, h.104.

${ }^{5}$ Philipus M. Hadjon, et.al., 1993, Pengantar Hukum Administrasi Negara Indonesia Introduction to the Indonesia Administrative Law), Gajah Mada University Pres, Yogjakarta, h. 128.

${ }^{6}$ Ibid., h. 153. hukum. Kedelapan asas tersebut adalah sebagai berikut :

1. Suatu sistem hukum terdiri dari peraturan-peraturan, tidak berdasarkan putusan-putusan sesaat untuk hal-hal tertentu (ad hoc),

2. Peraturan tersebut diumumkan kepada publik,

3. Tidak berlaku surut, karena akan merusak integritas sistem,

4. Dibuat dalam rumusan yang dimengerti oleh umum,

5. Tidak boleh ada peraturan yang saling bertentangan,

6. Tidak boleh menunrut suatu tindakan yang melebihi apa yang bisa dilakukan,

7. Tidak boleh sering diubah-ubah, dan

8. Harus ada kesesuaian antara peraturan dan pelaksanaan sehari-hari. ${ }^{7}$

\subsubsection{Asas Preferensi}

Ada tiga penyelesaian berkaitan dengan asas preferensi hukum yang meliputi asas lex superior derogate lex inferior, lex posteriori derogate lex priori, dan lex specialis derogat legi generali.

\subsection{Metode Penelitian}

\subsubsection{Jenis Penelitian}

Jenis penelitian ini adalah penelitian hukum normatif yang beranjak dari adanya permasalahan norma, yaitu konflik norma (geschijld van normen) antara pasal 330 BW dengan pasal 39 UU No.30 Tahun 2004 jo. UU No.2 Tahun 2014.

\subsubsection{Jenis Pendekatan}

Pendekatan yang digunakan untuk menganalisis permasalahan dalam penelitian ini meliputi : pendekatan Perundang-undang

${ }^{7}$ Lon L. Fuller dalam Achmad Ali, op.cit.. h. 294 . 
(Statue Approach), dan pendekatan Analisis Konsep

Hukum

(Analitical

\&

Conseptual

Approach),

\subsubsection{Sumber Bahan Hukum}

Dalam penelitian hukum ini menggunakan bahan hukum primer yang bersumber dari peraturan perundang-undangan, catatan-catatan resmi atau risalah dalam pembuatan perundang-undangan dan putusanputusan hakim yang bersifat autoritatif, dan hukum sekunder meliputi : buku-buku hukum (text book), jurnal-jurnal hukum, karya tulis hukum atau pandangan ahli hukum yang termuat dalam media massa.

\subsubsection{Teknik Pengumpulan Bahan Hukum}

Dengan pendekatan perundangundangan (the statute approach), maka mencari peraturan perundangundangan mengenai atau yang terkait dengan permasalahan hukum tersebut. Sedangkan dengan menggunakan pendekatan analisis konsep hukum (analytical \& conceptual approach), yang lebih esensial dilakukan adalah penelusuran buku-buku hukum (teratises).

\subsubsection{Teknik Analisis Bahan Hukum}

Dalam penelitian ini
menggunakan teknik analisis seperti deskripsi dan sistematisasi. Deskripsi berarti uraian apa adanya terhadap suatu kondisi atau posisi dari proposisi-proposisi hukum maupun non hukum. Teknik sistematisasi adalah berupa upaya mencari kaitan rumusan suatu konsep hukum atau proposisi hukum antara peraturan perundang-undangan yang sederajat maupun yang tidak sederajat.

\section{B A B II}

\section{TINJAUAN UMUM}

\subsection{Pengertian Kecakapan}

Tidak ada peraturan perundangundangan yang secara eksplisit menyebutkan definisi dari kecakapan. J. Satrio menyatakan bahwa :

"Kecakapan melakukan tindakan hukum dalam hukum perdata, dikaitkan dengan unsur kedewasaan dan hal itu secara tidak langsung ada kaitannya dengan unsur umur, akan tetapi dari ketentuanketentuan yang ada dalam BW, antara lain Pasal 307 jo Pasal 308, Pasal 383 BW, maupun Pasal 47 dan Pasal 50 UU No. 1 Tahun 1974 tentang Perkawinan, Pasal 1330 dan Pasal 1446 BW, orang bisa menyimpulkan bahwa pada asasnya yang dapat melakukan tindakan hukum secara sah dengan akibat hukum yang sempurna adalah mereka yang telah dewasa. Secara singkat, kecakapan bertindak bergantung dari kedewasaan yang dibatasi umur. ${ }^{8}$

\subsection{Batasan Umur Kecakapan}

\subsubsection{Berdasarkan}

Burgerlijk Wetboek (BW).

Pasal 1330 BW ini secara $a$ contrario ditafsirkan menjadi persyaratan dari kecakapan. Pasal 330 BW menyatakan, bahwa : "yang belum dewasa adalah mereka yang belum mencapai umur genap 21 (duapuluh satu) tahun dan tidak kawin sebelumnya." Beranjak dari penafsiran a-contrario terhadap substansi Pasal 1330 BW jo. 330 BW tersebut diatas dapat disimpulkan bahwa usia dewasa

${ }^{8}$ Ibid. 
adalah 21 (duapuluh satu) tahun atau telah kawin.

\subsubsection{Berdasarkan Hukum Adat}

Dewasa di dalam hukum adat tidak ditentukan dengan angka-angka yang pasti, melainkan dengan tandatanda atau peristiwa-peristiwa yang lazimnya bersifat monumental, misalnya perkawinan. Di samping itu, dalam berbagai kepustakaan ditegaskan bahwa seseorang dianggap dewasa apabila ia telah kuwat gawe (kuwat berarti mampu, gawe berarti pekerjaan). ${ }^{9}$

\subsubsection{Berdasarkan Kitab Undang- Undang Hukum Pidana dan Undang-Undang Republik Indonesia Nomor 3 Tahun 1997 Tentang Pengadilan Anak}

Abdul Rachmad Budiono menyatakan bahwa ;

"Dengan asas lex posteriori derograt lex priori, ketentuan di dalam pasal $45 \quad$ KUHP dikesampingkan oleh pasal 4 ayat (1) Undang-Undang Nomor 3 Tahun 1997. Ini berarti seseorang dapat dipertanggungjawabkan atas perbuatan pidana yang dilakukannya apabila telah berumur 18 tahun atau pernah kawin." 10

\subsubsection{Berdasarkan Undang-Undang Perkawinan}

Mencermati Pasal 66 UU No.1 Tahun 1974 , dengan menerapkan asas hukum "lex posteriori derogate legi priori”, maka seharusnya usia dewasa yang mendasarkan ketentuan Pasal 330 jo. Pasal 1330 BW menjadi absurd dan melanggar asas hukum dimaksud. ${ }^{11}$

Dengan demikian, usia dewasa terkait dengan

9 Abdul Rachmad Budiono, 2005, Pengantar Ilmu Hukum, Bayu Media, Malang, h.57

${ }^{10}$ Ibid., h.59.

11 Agus Yudha Hernoko, 2010, Hukum Perjanjian - Asas Proporsionalitas Dalam Kontrak Komersil, Kencana, Jakarta, h.188. kecakapan melakukan perbuatan hukum adalah 18 tahun mengacu pada Pasal 47 dan Pasal 50 UU No. 1 Tahun 1974. Hal ini juga dipertegas juga berdasarkan Petunjuk MA No. MA/Pemb/0807/75 dan Putusan MA No. 477K/Sip/1976, tanggal 13-10-1976. ${ }^{12}$

\subsubsection{Berdasarkan Undang-Undang Jabatan} Notaris

Pasal 39 dan Pasal 40 UU No.30 Tahun 2004 jo. UU No.2 Tahun 2014 menyatakan bahwa syarat untuk menjadi penghadap dan saksi di antaranya adalah paling rendah berumur 18 (delapanbelas) tahun atau telah menikah dan cakap melakukan perbuatan hukum. Dengan demikian, umur 18 (delapanbelas) tahun dianggap oleh pembuat undang-undang telah dapat dibebani tanggung jawab hukum, sebagaimana diatur dalam Pasal 39 ayat (1).

\subsection{Akibat Hukum Ketidakcakapan}

Suatu perjanjian yang tidak memenuhi syarat sah sebagaimana yang diatur dalam Pasal 1320 BW, baik syarat subjektif maupun syarat objektif akan mempunyai akibatakibat, sebagai berikut $:^{13}$

a. Non-eksistensi, apabila tidak ada kesepakatan maka tidak timbul perjanjian.

b. Vernietigbaar atau dapat dibatalkan, apabila perjanjian tersebut lahir karena adanya cacat kehendak (wilsgebreke) atau karena ketidakcakapan (onbekwaamheid) - (Pasal 1320 BW syarat 1 dan 2), berarti hal ini terkait dengan unsur sujektif, sehingga berakibat perjanjian tersebut dapat dibatalkan, dan

12 J. Satrio, 2000, Hukum Perjanjian, Citra Aditya Bakti, Bandung, h.279.

${ }^{13}$ Agus Yudha Hernoko, op.cit., h.160 
c. Nietig atau batal demi hukum, apabila terdapat perjanjian yang tidak memenuhi syarat objek tertentu atau tidak mempunyai causa atau causanya tidak diperbolehkan (Pasal 1320 BW syarat 3 dan 4), berarti hal ini terkait dengan unsur objektif, sehingga berakibat perjanjian tersebut batal demi hukum.

\subsection{Pengertian Hak Tanggungan}

Dalam pasal 1 ayat (1) UU No.4 Tahun 1996 disebutkan pengertian hak tanggungan. Yang dimaksud dengan hak tanggungan adalah :

"Hak Tanggungan atas tanah beserta benda-benda yang berkaitan dengan tanah, yang selanjutnya disebut Hak Tanggungan, adalah hak jaminan yang dibebankan pada hak atas tanah sebagaimana dimaksud dalam Undang-Undang Nomor 5 Tahun 1960 tentang Peraturan Dasar PokokPokok Agraria, berikut atau tidak berikut bendabenda lain yang merupakan satu kesatuan dengan tanah itu, untuk pelunasan utang tertentu, yang memberikan kedudukan yang diutamakan kepada kreditor tertentu terhadap kreditor-kreditor lain”

\subsection{Dasar Hukum Hak Tanggungan}

Sebelum berlakunya UU No.4 Tahun 1996, maka peraturan perundang-undangan yang mengatur tentang pembebanan hak tas tanah adalah Bab 21 Buku II BW, yang berkaitan dengan hipotek dan creditverband dalam Staatsblad 1908542 sebagaimana telah diubah dengan Staatsblad 1937-190. Dalam Pasal 51 UU No.5 Tahun 1960, sudah disediakan lembaga hak jaminan yang kuat yang dapat dibebankan pada hak atas tanah, yaitu Hak Tanggungan.

\subsection{Subjek Hak Tanggungan}

Subjek hak tanggungan diatur dalam Pasal 8 dan Pasal 9 UU No.4 Tahun 1996, bahwa yang dapat menjadi subjek hak tanggungan dalam pembebanan hak tanggungan adalah pemberi hak tanggungan dan pemegang hak tanggungan. Pemberi hak tanggungan dapat perorangan atau badan hukum, yang mempunyai tanggungan. Pemegang hak tanggungan terdiri dari perorangan atau badan hukum yang berkedudukan sebagai pihak berpiutang.

\subsection{Objek Hak Tanggungan}

Dalam Pasal 4 sampai dengan Pasal 7 Undang-Undang Nomor 4 Tahun 1996 telah ditunjuk secara tegas hak atas tanah yang dapat dijadikan jaminan hutang. Ada lima jenis hak tas tanah yang dapat dijaminkan dengan hak tanggungan, yaitu : Hak milik, Hak Guna Usaha, Hak Guna Bangunan, Hak Pakai, baik hak milik maupun hak atas negara, dan Hak atas tanah berikut bangunan, tanaman, dan hasil karya yang telah ada atau akan ada merupakan satu kesatuan dengan tanah tersebut.

\subsection{Surat Kuasa Membebankan Hak}

\section{Tanggungan}

Hanya apabila benar-benar diperlukan, yaitu dalam hal pemberi hak tanggungan tidak dapat hadir dihadapan PPAT, diperkenankan penggunaan SKMHT. Sejalan dengan itu, surat kuasa tersebut harus diberikan langsung oleh pemberi hak tanggungan dan harus memenuhi persyaratan mengenai muatannya sebagaimana ditetapkan pada paal 15 ayat (1) UU No.4 Tahun 1996. 
SKMHT dapat dibuat secara notariil atau melalui akta PPAT.

\subsection{Notaris}

Dalam Pasal 1 angka 1 UU No. 30 Tahun 2004 jo. UU No.2 Tahun 2014 diatur bahwa : "Notaris adalah pejabat umum yang berwenang untuk membuat akta autentik dan memiliki kewenangan lainnya sebagaimana dimaksud dalam Undang-Undang ini atau berdasarkan undang-undang lainnya".

\subsection{Pejabat Pembuat Akta Tanah} (PPA T)

Pasal 1 angka 1 PP No. 37 Tahun 1998 yang menyatakan bahwa PPAT adalah pejabat umum yang diberi kewenangan untuk membuat akta-akta otentik mengenai perbuatan hukum tertentu menyangkut hak atas tanah atau hak milik atas satuan rumah susun. PPAT diangkat dan diberhentikan oleh Menteri (sekarang Kepala BPN) untuk suatu daerah kerja tertentu.

\section{B A B III}

\section{BATASAN UMUR KECAKAPAN \\ MEMBUAT SURAT KUASA \\ MEMBEBANKAN HAK \\ TANGGUNGA N}

\subsection{Kewenangan Notaris Dalam Pembuatan SKMHT}

Ketentuan Pasal 15 ayat (3) UU No.30 Tahun 2004 memberikan dasar hukum atas kewenangan lain yang tidak diatur dalam UU No.30 Tahun 2004 jo. UU No.2 Tahun 2014. Kewenangan notaris tidak hanya sebagaimana yang ditentukan dalam Pasal 15 UU No.30 Tahun 2004 jo. UU No.2 Tahun 2014, namun juga diatur dalam peraturan perundang-undangan diluar UU No.30 Tahun 2004 jo. UU No.2 Tahun 2014, seperti kewenangan membuat SKMHT. Kewenangan notaris dalam pembuatan SKMHT diatur dalam ketentuan Pasal 15 UU No.4 Tahun 1996.

\subsection{Batasan Umur Membuat SKMT Notariil}

Terdapat 2 (dua) ketentuan hukum mengenai batasan umur dalam pembuatan SKMHT, sehingga menimbulkan konflik norma (geschijld van normen) horizontal antara Pasal 330 BW dengan Pasal 39 ayat (1) UU No.30 Tahun 2004 jo. UU No2 Tahun 2014. Berdasarkan asas lex specialis derogat legi generali, maka Pasal 39 ayat (1) UU No.30 Tahun 2004 jo. UU No.2 Tahun 2014 mengesampingkan Pasal 330 BW. Seharusnya notaris dalam pembuatan SKMHT mengacu paling rendah berumur 18 tahun sesuai Pasal 39 ayat (1) UU No.30 Tahun 2004 jo. UU No.2 Tahun 2014.

\subsection{Kewenangan PPAT Dalam \\ Pembuatan SKMHT}

Ketentuan Pasal 3 ayat (1), Pasal 2 ayat (2) PP No.37 Tahun 1998, Pasal 2 ayat (2) dan Pasal 3 ayat (1) PKBPN No.1 Tahun 2006, Pasal 95 ayat (2) PMNA/KBPN No.3 Tahun 1997 dan Pasal 15 ayat (1) UU No.4 Tahun 1996 merupakan dasar hukum atas kewenangan PPAT dalam pembuatan SKMHT. Kewenangan PPAT membuat SKMHT yang ditentukan pada Pasal 15 ayat (1) UU No.4 Tahun 1996 merupakan kewenangan atribusi yang bersumber dari undang-undang. 
3.4.Batasan Umur Membuat SKMHT Dihadapan PPAT

PPAT dalam menjalankan pembuatan SKMHT mengacu pada ketentuan Pasal 330 BW, yaitu umur dewasa 21 (duapuluh satu) tahun. ${ }^{14}$ Mencermati pasal 66 UU No.1 Tahun 1974, dengan menerapkan asas hukum "lex posteriori derogate legi priori", maka seharusnya pasal 330 jo. 1330 BW tidak lagi dijadikan sumber hukum. Dengan demikian, usia dewasa yang berlaku secara umum terkait dengan kecakapan untuk melakukan perbuatan hukum adalah 18 (delapanbelas) tahun. ${ }^{15} \mathrm{Hal}$ ini juga dipertegas oleh Mahkamah Agung Republik Indonesia melalui Petunjuk MA No. MA/Pemb/0807/75 dan Putusan MA No. 477K/Sip/1976, tanggal 13-10-1976. ${ }^{16}$ Secara normatif seharusnya PPAT mengacu pada batasan umur dewasa yang telah ditentukan dalam ketentuan-ketentuan UU No.1 Tahun 1974, yaitu umur 18 (delapanbelas) tahun.

\footnotetext{
${ }^{14}$ Ningrum Puji Lestari, 2008, Kecakapan Bertindak Dalam Melakukan Perbuatan Hukum Setelah Berlakunya Undang-Undang No. 30 Tahun 2004 Tentang Jabatan Notaris, Tesis, Program Studi Magister Kenotariatan, Program Pasca Sarjana, Universitas Diponegoro, Semarang, h. 54 .

${ }^{15}$ Agus Yudha Hernoko, op.cit., h.188.

16 J. Satrio, 2000, Hukum Perjanjian, Citra Aditya Bakti, Bandung, h.19.
}

B A B IV

BATASAN UMUR KECAKAPAN

MEMBUAT

AKTA PEMBERIAN HAK

TANGGUNGAN DAN

PENDAFTARAN HAK

TANGGUNGAN

\subsection{Kewenangan PPAT dan Batasan}

\section{Umur Dalam Pembuatan APHT}

Pemberian Hak Tanggungan dilakukan dengan pembuatan APHT oleh PPAT sesuai dengan ketentuan Pasal 10 ayat (2) UU No.4 Tahun 1996. Ketentuan tersebutlah yang menjadi dasar kewenangan bagi PPAT dalam pembuatan APHT. Ketentuan Pasal 3 ayat (1), Pasal 2 ayat (2) PP No.37 Tahun 1998, Pasal 2 ayat (2) dan Pasal 3 ayat (1) Peraturan Kepala BPN No.1 Tahun 2006, dan Pasal 10 ayat (2) UU No.4 Tahun 1996 merupakan dasar hukum atas kewenangan PPAT dalam pembuatan akta otentik APHT.

PPAT mendasarkan kecakapan orang perseorangan menurut umur pada ketentuan pasal 330 BW, yaitu 21 (duapuluh satu) tahun atau telah kawin. ${ }^{17}$ Berdasarkan pasal 66 UU No.1 Tahun 1974, dengan menerapkan asas hukum "lex posteriori derogate legi priori", maka seharusnya ketentuan pasal 330 jo. 1330 BW tidak lagi dijadikan sumber hukum, namun mengacu pada Pasal 47 dan Pasal 50 UU No. 1 Tahun 1974, bahwa usia dewasa terkait dengan kecakapan untuk melakukan perbuatan hukum

${ }^{17}$ Vera Oktarina, 2009, Pengaturan Kedewasaan Dalam Pembuatan Akta Notaris Dan Akta PPAT, Tesis. Program Studi Magister Kenotariatan, Fakultas Hukum, Universitas Airlangga, Surabaya, h.12. 
adalah 18 tahun. Hal ini juga dipertegas oleh Mahkamah Agung Republik Indonesia melalui Petunjuk MA No. MA/Pemb/0807/75 dan Putusan MA No. 477K/Sip/1976, tanggal 13-10-1976. Dengan demikian seharusnya PPAT dalam pembuatan APHT dan akta-akta tanah lain mengacu pada batasan umur dewasa yang telah ditentukan dalam ketentuan-ketentuan UU No.1 Tahun 1974, yaitu menggunakan batasan umur 18 (delapanbelas) tahun.

\subsection{Persiapan Pembuatan Akta Pemberian Hak Tanggungan (APHT)}

PPAT terlebih dahulu melakukan tahapan persiapan pembuatan akta sebagaimana diatur dalam Pasal 97 PMNA/KBPN No.3 Tahun 1997 sebelum membuat akta. Sebelum pembuatan APHT, PPAT wajib terlebih dahulu melakukan pemeriksaan pada Kantor Pertanahan mengenai kesesuaian sertipikat hak atas tanah yang bersangkutan dengan daftar-daftar yang ada di Kantor Pertanahan.

\subsection{Pembuatan Akta Pemberian Hak Tanggungan (APHT) \\ Pembuatan APHT harus dihadiri} oleh para pihak yang melakukan perbuatan hukum yang bersangkutan atau orang yang dikuasakan olehnya dengan surat kuasa tertulis sesuai dengan peraturan perundang-undangan yang berlaku. Pasal 10 UU No.4 Tahun 1996 mengatur bahwa APHT wajib dibuat di muka dan dihadapan PPAT. Isi APHT telah diatur dalam Pasal 11 UU No.4 Tahun 1996, sedangkan bentuk dan tata cara pengisian APHT harus dibuat sesuai dengan Lampiran Peraturan Kepala BPN No.8 Tahun 2012 sebagaiman diatur pada Pasal 96 PMNA/KBPN No. 3 Tahun 1997 jo. Peraturan Kepala BPN No.8 Tahun 2012.

\subsection{Akibat Hukum APHT Yang Menggunakan SKMHT Notariil}

Akan muncul permasalahan hukum apabila menggunakan SKMHT notariil yang subjeknya, baik pemberi kuasa maupun penerima kuasa belum dewasa secara BW, artinya belum berumur 21 (duapuluh satu) tahun namun telah berumur 18 (delapan belas) tahun. Meskipun SKMHT tersebut telah dibuat secara sah berdasarkan ketentuan-ketentuan Pasal 1320 BW, Pasal 15 UU No.4 Tahun 1996, dan UU N0.30 Tahun 2004 jo. UU No.2 Tahun 2014, namun tidak akan dapat dilanjutkan pada proses pembuatan APHT.

\subsection{Pendaftaran Hak Tanggungan}

Pendaftaran hak tanggungan diatur dalam Pasal 13 dan Pasal 14 UU No.4 Tahun 1996. Mengenai pendaftaran diatur dalam Pasal 40 ayat (1) PP No.24 Tahun 1997 bahwa selambat-lambatnya 7 hari kerja sejak tanggal ditandatanganinya APHT. Tata cara pendaftaran hak tanggungan diatur pada Pasal 114 sampai dengan Pasal 119 PMNA/KBPN No.3 Tahun 1997. Salah satu syarat wajib pendaftaran hak tanggungan adalah PPAT wajib mengirimkan APHT yang bersangkutan kepada Kantor Pertanahan. Apabila pembuatan APHT karena permasalahan umur kecakapan, maka akan berakibat pula tidak dapat dilakukan pendaftaran hak tanggungan ke Kantor Pertanahan karena salah satu syaratnya (APHT) tidak terpenuhi. Tidak dapat dilakukannya 
proses pendaftaran hak tanggungan, maka akan berakibat hak tanggungan tidak lahir.

4.6. Batasan Umur Kecakapan Dalam Pendaftaran Hak Tanggungan

Pada proses pendaftaran hak tanggungan di Kantor Pertanahan sampai saat ini masih berpegang pada batasan umur 21 (duapuluh satu) tahun atau telah kawin dianggap cakap hukum sebagaimana diatur pada Pasal 330 BW, sebagaimana tampak dari Surat Edaran Departemen Dalam Negeri Direktorat Jenderal Agraria Direktorat Pendaftaran Tanah (Kadaster) Nomor Dpt.7/539/7.77 tertanggal 13 Juli $1977 .^{18}$

\subsection{Pengaturan Batasan Umur Kecakapan}

Ketentuan batasan umur cakap hukum sampai saat ini pengaturannya masih berbeda-beda. Perlu diketahui ukuran umur dewasa di beberapa negara lain sebagai suatu perbandingan hukum. Di Belanda telah menggunakan acuan usia 18 (delapanbelas) tahun sebagai standar usia dewasa (kecakapan melakukan perbuatan hukum). ${ }^{19}$ Di Inggris dalam sec 1 of the family Law Reform Act maupun Minors Contract Act 1987, telah menurunkan standar usia 21 (duapuluh satu) tahun menjadi 18 (delapanbelas) tahun untuk kategori "minors or infants". ${ }^{20} \mathrm{Di}$ Australia

18 Ade Maman Suherman dan J. Satrio, 2010, Penjelasan Hukum Tentang Batasan Umur (Kecakapan dan Kewenangan Bertindak Berdasar Batasan Umur), Legal Reform Program Nasional, Jakarta, h.19.

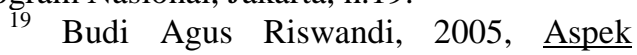
Hukum Internet Banking, Raja Grafindo Persada, Jakarta, h.154.

20 J. Beatson, 2002, Anson's Law of Contract, Oxford University, London, h.215
(New South Wales), melalui The Minor (Property and Contract) Act 1970, ditegaskan bahwa, “This Act provides that minors will be bound by 'civil acts' once they reach the age of eighteen years."21 Di Malaysia berdasarkan Akta Umur Dewasa 1971, ditegaskan bahwa umur dewasa adalah 18(delapanbelas) tahun. ${ }^{22}$ Di Indonesia telah memakai ukuran 18 tahun berdasarkan UU No.1 Tahun 1974, UU No. 30 Tahun 2004 jo. UU No.2 Tahun 2014, dan beberapa peraturan perundang-undangan lain. UU No.1 Tahun 1974 berpegang kepada usia dewasa 18 tahun adalah sangat tepat sebagai acuan batasan umur dewasa yang cakap untuk masyarakat Indonesia saat ini.

\section{BA B V}

\section{KESIMPULAN DAN SARAN}

\subsection{Kesimpulan}

Seharusnya batasan umur cakap membuat SKMHT notariil adalah 18 tahun sebagaimana diatur dalam Pasal 39 UU No.30 Tahun 2004 jo. UU No.2 Tahun 2014. Apabila SKMHT dibuat dengan akta PPAT, maka seharusnya juga menggunakan batasan umur 18 tahun berdasarkan penerapan asas "lex posteriori derogate legi priori", Pasal 47, Pasal 50, Pasal 66 UU No.1 Tahun 1974

Petunjuk

MA

No.MA/Pemb/0807/75, Putusan MA No.477K/Sip/1976, tanggal 13-101976 .

21 M. L. Barron, 1998, Fundamental of Bussiness Law, McGraw Hill Book Co., Sydney, h.181.

${ }^{22}$ Sakina Shaik Ahmad Yusoof dan Amizon Abdul Azis, 2003, Mengenal Undang-undang Kontrak Malaysia, International Law Book Series, Kuala Lumpur, h.82. 


Proses pembuatan
dihadapan PPPAT tidak akan dapat
dilakukan apabila menggunakan
SKMHT notariil yang subjeknya
berumur 18 tahun. Sehingga proses
pendaftaran hak tanggungan juga
tidak dapat dilakukan. PPAT dan BPN
menggunakan batasan umur 21
(duapuluh satu) tahun berdasarkan
Pasal 330 BW. Seharusnya PPAT dan
BPN menggunakan batasan umur 18
(delapanbelas) tahun berdasarkan
Pasal 47, Pasal 50, Pasal 66 UU No.1
Tahun $1974, \quad$ Petunjuk MA
No.MA/Pemb/0807/75, dan Putusan
MA No.477K/Sip/1976, tanggal $13-10-$
1976.

\begin{abstract}
5.2. Saran
Kepada para notaris agar konsisten menerapkan ketentuanketentuan dalam UU No.30 Tahun 2014 jo. UU No.2 Tahun 2014 sebagai landasan hukum jabatan notaris. Kepada PPAT sebagai pembuat aktaakta otentik pertanahan dan BPN diharapakan merubah batasan umur dewasa 21 tahun menjadi 18 tahun. Kepada Pemerintah dan DPR selaku pembuat undang-undang segera membuat suatu undang-undang umum yang mengatur secara tegas batasan umur dewasa 18 (delapanbelas) tahun.
\end{abstract}

\title{
DAFTAR PUSTAKA
}

Sudarsono, 2007, Pengantar Ilmu Hukum, cet.V, Rineka Cipta, Jakarta.

Asshiddiqie, Jimly, 2005, Konstitusi dan Konstitusionalisme Indonesia, Konpress, Jakarta.

Ali, Achmad, 2009, Menguak Teori Hukum (Legal Theory) dan Teori Peradilan (Judicialprudence), Kencana, Jakarta.

HR., Ridwan, 2006, Hukum Administrasi Negara, Raja Grafmdo Persada, Jakarta.

Hadjon, Philipus M, et.al., 1993, Pengantar Hukum Administrasi Negara Indonesia (Introduction to the Indonesia Administrative Law), Gajah Mada University Pres, Yogjakarta.

Subekti, 2005, Hukum Perjanjian, Intermasa, Jakarta.

Suherman, Ade Maman, dan J. Satrio, 2010, Penjelasan Hukum Tentang Batasan Umur (Kecakapan dan Kewenangan Bertindak Berdasar Batasan Umur), Legal Reform Program Nasional, Jakarta.

Budiono, Abdul Rachmad, 2005, Pengantar Ilmu Hukum, Bayu Media, Malang.

Hernoko, Agus Yudha, 2010, Hukum Perjanjian - Asas Proporsionalitas Dalam Kontrak Komersil, Kencana, Jakarta.

Satrio, J., 2000, Hukum Perjanjian, Citra Aditya Bakti, Bandung.

Satrio, J., 2004, Hukum Jaminan, Hak Jaminan Kebendaan, Hak Tanggungan Buku II, Citra Aditya Bakti, Bandung.

Budiono, Herlien, 2008, Kumpulan Tulisan Hukum Perdata Di Bidang Kenotariaatan, cet.II, Citra Aditya Bakti, Bandung.

Puji Lestari, Ningrum, 2008, Kecakapan Bertindak Dalam Melakukan Perbuatan Hukum Setelah Berlakunya Undang-Undang No. 30 Tahun 2004 Tentang Jabatan Notaris, Tesis, Program Studi Magister Kenotariatan, Program Pasca Sarjana, Universitas Diponegaoro, Semarang.

Satrio, J., 2000, Hukum Perjanjian, Citra Aditya Bakti, Bandung.

Oktarina, Vera, 2009, Pengaturan Kedewasaan Dalam Pembuatan Akta Notaris Dan Akta PPAT, Tesis. Program Studi Magister Kenotariatan, Fakultas Hukum, Universitas Airlangga, Surabaya. 
Riswandi, Budi Agus, 2005, Aspek Hukum Internet Banking, Raja Grafindo Persada, Jakarta.

Beatson, J., 2002, Anson's Law of Contract, Oxford University, London.

Barron, M. L., 1998, Fundamental of Bussiness Law, McGraw Hill Book Co., Sydney.

Ahmad Yusoof, Sakina Shaik, dan Amizon Abdul Azis, 2003, Mengenal Undang-undang Kontrak

Malaysia, International Law Book Series, Kuala Lumpur.

\section{Peraturan Perundang-Undangan ;}

Burgerlijk Wetboek, Stb. 1847-23.

Undang-Undang Republik Indonesia Nomor 4 Tahun 1996 Tentang Hak Tanggungan

Atas Tanah Beserta Benda-Benda Yang Berkaitan Dengan Tanah, Lembaran Negara Republik Indonesia Tahun 1996 Nomor 42, Tambahan Lembaran Negara Republik Indonesia Nomor 3632.

Undang-Undang Republik Indonesia Nomor 30 Tahun 2004 Tentang Jabatan Notaris,

Lembaran Negara Republik Indonesia Tahun 2004 Nomor 117, Tambahan

Lembaran Negara Republik Indonesia Nomor 4432.

Undang-Undang Republik Indonesia Nomor 2 Tahun 2014 Tentang Perubahan Atas

Undang-Undang Nomor 30 Tahun 2004 Tentang Jabatan Notaris, Lembaran

Negara Republik Indonesia Tahun 2014 Nomor 3, Tambahan Lembaran Negara Republik Indonesia Nomor 5491.

Peraturan Pemerintah Republik Indonesia Nomor 24 Tahun 1997 Tentang Pendaftaran

Tanah, Lembaran Negara Republik Indonesia Tahun 1997 Nomor 59, Tambahan Lembaran Negara Republik Indonesia 3696.

Surat Edaran Mahkamah Agung Republik Indonesia Nomor 3 Tahun 1963 tanggal 5 September 1963.

Surat Edaran Departemen Dalam Negeri Direktorat Jenderal Agraria Direktorat Pendaftaran Tanah (Kadaster) Nomor Dpt. 7/53 9/7.77 tanggal 13 Juli 1977 Tentang Dewasa Hukum. 